\title{
THE FAILURE OF THE COPPER IUD TO INHIBIT FERTILIZATION IN THE RABBIT
}

\author{
J. P. POLIDORO AND D. L. BLAGK \\ Laboratory for Reproductive Physiology, Department of Veterinary and Animal Sciences, \\ University of Massachusetts, Amherst, Massachusetts, U.S.A. \\ (Received 20th March 1970, revised 8th June 1970)
}

The effect of intra-uterine devices (IUDs) in rabbits is variable. Depending on size, intra-uterine threads and plastic IUDs cause incomplete and localized reductions in fertility (Brown \& Foote, 1966; Marston \& Chang, 1969). Recently, the use of copper coils in rabbits and copper wire (in combination with plastic ' $T$ ' devices) in humans has been shown to decrease implantation rates (Zipper, Medel \& Prager, 1969; Zipper, Tatum, Pastene, Medel \& Rivera, 1969). Although the mechanism of action is not known, there is some evidence that copper exerts a toxic effect on spermatozoa (Saito, Bush \& Whitmore, 1967). The following study was undertaken to determine if the complete inhibition of implantation as seen in the rabbit with a copper IUD is the result of fertilization failure.

Twelve mature, virgin, Dutch-belted rabbits were divided into three groups of four does each:

Group 1: (implantation study). IUD in one horn; mated and subsequently killed 10 days post coitum (p.c.); viable and degenerate implantations recorded.

Group 2: (uterine anastomosis). Same as Group 1, but with surgical communication between horns.

Group 3: (fertilization study). IUD in one horn; mated and oviducts flushed $48 \mathrm{hr}$ p.c. (fertilization rate determined).

They were housed individually and allowed free access to pelleted feed and water.

The ' $U$ '-shaped IUDs $(1.0 \mathrm{~cm})$ were made by bending copper wire $(2.0 \mathrm{~cm}$; No. 16 gauge) upon itself and were inserted at random through the uterine wall into one uterine horn at mid-ventral laparotomy under sodium pentobarbital anaesthesia. The IUD was designed to prevent occlusion of the uterine lumen. The device was tied in place by one ligature which passed through the 'eyelet' of the closed end (Text-fig. 1) $1 \mathrm{~cm}$ above the end of the uterine horn (free end cervically) and the point of insertion sutured by one catgut ligature (3-0). In Groups 1 and 3, contralateral sides served as controls. In Group 2, communication between uterine horns was accomplished by surgical anastomosis of the antimesometrial surfaces ( 5 to $7 \mathrm{~mm}$ ) of both horns anterior and proximal to the IUD (Text-fig. 1). All of the animals were allowed a 1-week period of 
recuperation before they were mated to males of known fertility and were then immediately injected with $2.5 \mathrm{mg} \mathrm{LH} \mathrm{(Mann} \mathrm{Research)} \mathrm{to} \mathrm{support} \mathrm{the} \mathrm{stimulus}$ to ovulation.

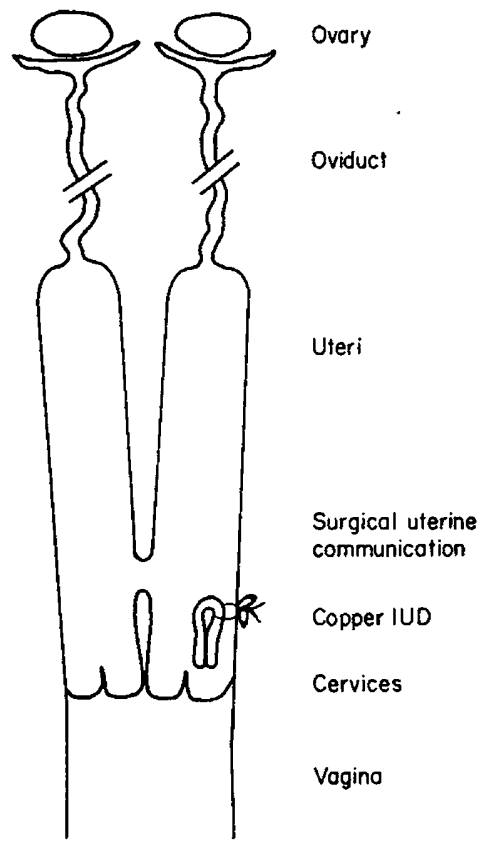

Text-Fig. 1. Schematic illustration of a rabbit reproductive tract with a surgical communication between uterine horns and a unilaterally located copper IUD.

TABLE 1

EFFECT OF A COPPER IUD AND UTERINE ANASTOMOSIS ON IMPLANTATION IN THE RABBIT

\begin{tabular}{|c|c|c|c|c|c|c|}
\hline & & & & Total no. of & implantation & \\
\hline & & $f C L$ & & iable & Deg & enerate \\
\hline & $\begin{array}{c}\text { Control } \\
\text { ovary }\end{array}$ & IUD ovary & $\begin{array}{c}\text { Non-IUL } \\
\text { horn }\end{array}$ & IUD horn & $\begin{array}{c}\text { Non-IUD } \\
\text { horn }\end{array}$ & IUD horn \\
\hline $\begin{array}{l}\text { Group } 1 \\
\text { Group } 2\end{array}$ & $\begin{array}{l}23 \\
17\end{array}$ & $\begin{array}{l}13 \\
22\end{array}$ & $\begin{array}{r}16 \\
1\end{array}$ & $\begin{array}{l}0 \\
6\end{array}$ & $\begin{array}{l}1 \\
7\end{array}$ & $\begin{array}{l}0 \\
7\end{array}$ \\
\hline
\end{tabular}

The results of both implantation studies (Groups 1 and 2) are shown in Table 1. In these groups, the numbers of viable and degenerate implantation sites in each horn were recorded and compared with the respective number of corpora lutea (CL) on each ovary. On the 10th day of pregnancy (Group 1), there were no implantations in the uterine horns containing a copper IUD. All but one of the implantations in the control horns, however, were normal in size and appearance. These results confirm the data of Zipper et al. (1969) which revealed a complete contraceptive effect by a copper IUD. 
To determine if this effect was localized and/or mediated through the uterine secretions, animals in Group 2 were killed 10 days p.c., the patency of the communication between the uterine horns was confirmed and the number of implantations recorded. Implantations were found in three of the four animals and in both uterine horns. Only seven implantations were viable (normal size and placental development) and they were positioned in the anterior portion of the uteri far from the IUD. Ten of the fourteen degenerate implantations, in this group, were small and poorly formed (approx. $5.0 \mathrm{~mm}$ in diameter). In the remaining animal of the group, there were eleven ovulations but no implantations. The greater number of viable implantations on the IUD side was the result of animal variability. This indicated that the uterine secretion failed to reach the anterior portion of the horn and not that the IUD failed to affect these implantations.

Since copper can be toxic to spermatozoa (Saito et al., 1967), a depressive effect on fertilization is a possible mode of action of the copper IUD (Zipper et al., 1969). Animals in the fertilization study (Group 3) were killed $48 \mathrm{hr}$ p.c., the oviducts were flushed with $0.9 \%$ saline and the ova examined for cleavage. As can be seen from Table 2, all the ova recovered (IUD side) were fertilized (two- to four-cell stage). Reduced implantation, therefore, was not caused by a toxic effect of the copper IUD on spermatozoa.

TABLE 2

FERTILIZATION IN RABBITS WITH A COPPER IUD

\begin{tabular}{l|c|c|c|c|c|c|c}
\hline & \multicolumn{2}{|c|}{ No. of $C L$} & \multicolumn{2}{c|}{ Total no. of ova recovered } & \multicolumn{2}{c}{ No. of ova fertilized } \\
\cline { 2 - 7 } & Control ovary & IUD ovary & Control side & IUD side & Control & IUD \\
\hline Group 3 & 18 & 18 & 12 & 16 & 11 & 16 \\
\hline
\end{tabular}

In some animals (Groups 1 and 2), a brown uterine exudate was found in the horn which contained the IUD; this was not observed in Group 3. Since it occurred only in the implantation groups, it probably resulted from the resorbing implantation sites; a similar exudate is seen in overcrowded uteri. At necropsy, all the ovaries and cL (Groups 1, 2 and 3) appeared macroscopically normal and all but one of the IUDs were in their original positions. The one dislodged IUD was located just below the tubo-uterine junction (Group 1 animal).

In conclusion, the reduction in the number of implantations in the rabbits with copper IUDs is not caused by fertilization failure, but appears to be mediated locally by the uterine fluids and affects only the endometrial areas that come in contact with the secretion.

\section{REFERENCES}

Brown, E. \& Foote, R. H. (1966) The effect of plastic devices in the uterine lumen on pregnancy and parturition in the rabbit. 7. Reprod. Fert. 12, 373.

Marston, J. H. \& Chang, M. C. (1969) Contraceptive action of intra-uterine devices in the rabbit. J. Reprod. Fert. 18, 409. 
Satto, S., Busf, I. M. \& Whitmore, W. F. (1967) Effects of certain metals and chelating agents on rat and dog epididymal spermatozoan motility. Fert. Steril. 18, 517.

Zipper, J., Meded, M. \& PRAger, R. (1969) Suppression of fertility by intra-uterine copper and zinc in rabbits. Am. F. Obstet. Gynec. 105, 529.

Zipper, J., Tatum, H. J., Pastene, L., Meder, M. \& Rivera, M. (1969) Metallic copper as an intrauterine contraceptive adjunct to the "T" device. Am. F. Obstet. Gynec. 105, 1274. 